\title{
Governments Are Constitutionally Permitted to Provide "Vaccine Passports"-Some May Also Be Constitutionally Obligated to Do So
}

\author{
Kevin Cope $^{1}$ and Alexander Stremitzer ${ }^{2}$ \\ ${ }^{1}$ University of Virginia Law School, Charlottesville, Virginia; and ${ }^{2}$ Center for Law and Economics, ETH Zürich, Zürich, Switzerland, \\ and UCLA School of Law, Los Angeles, California
}

$\mathbf{I}$ early April, as daily U.S. vaccine doses reached 4 million, Florida Governor Ron DeSantis banned private businesses from requiring proof of COVID-19 vaccination-so-called vaccine passports - as a condition of service. DeSantis echoed the concerns of some other conservative pundits and policymakers, arguing that the passports would "reduce individual freedom" and "create two classes of citizens." In March, Ohio Republican U.S. Senate candidate Josh Mandel tweeted that "Vaccine Passports trample on human liberty." These arguments hint that vaccine passports would offend fundamental freedoms, and possibly even constitutional ones, if implemented with the government's blessing. Some groups, including a Canadian antivaccination organization, have made this argument explicitly (1).

These views notwithstanding, government-provided vaccine passports would most certainly pass muster under many national legal systems, including under Israeli Basic law, British law, and U.S. constitutional law (2). But more than that, we believe that, assuming governments do not lift COVID restrictions for everybody, exempting vaccinated people from COVID-related restrictions might even be required under some constitutional systems. Given the policy choice between (1) a vaccine passport program - which would soon allow vaccinated people to, for example, travel, attend political events, and congregate for religious services freely - and (2) ongoing, blanket government bans on those activities - which allow no one to do those things - the former is less constitutionally problematic.

All modern constitutional systems recognize that citizens enjoy a set of fundamental rights. In general, governments can restrict certain fundamental rights only if no less-restrictive alternatives exist for accomplishing the same objectives. In countries such as Germany, Austria, and Switzerland, this argument holds generally under the so-called proportionality test. In the United States, governments may not tread on fundamental rights unless the policy is "the least restrictive means" to achieve a "compelling" government interest. Even some rights considered nonfundamental may not be infringed without a rational or nonarbitrary reason (3).

While full restrictions on certain fundamental life activities typically trigger the highest level of U.S. constitutional scrutiny, treating

\footnotetext{
For correspondence or reprints, contact Alexander Stremitzer (astremitzer@ ethz.ch).

Published online Apr. 16, 2021

COPYRIGHT (C) 2021 by the Society of Nuclear Medicine and Molecular Imaging DOI: 10.2967/jnumed.121.262434
}

people differently based on engaging in certain voluntary acts, such as not receiving a vaccination, often involve the lowest level. In fact, U.S. courts have repeatedly upheld schools' and state requirements that exclude or penalize those who do not receive certain vaccinations (4).

Throughout 2020, when temporary bans on certain high-risk, nonessential activities such as high-density religious services (5), political rallies (6), public dining, theater attendance, and international travel were challenged, they generally (though not always) passed constitutional muster. For good reason, national legal systems tend to defer to officials' policy judgments when it comes to combating public health crises. And indeed, many of those measures represented the best available means to slow the virus.

As we approach wider vaccine availability, however, that is no longer the case. Now, facilitating mass immunity - and exempting the immunized from restrictions - is not only the least libertyrestricting method for ending the pandemic through herd immunity, but also the most effective one. Some vaccines are more than $90 \%$ effective at preventing infection (and nearly 100\% effective at preventing serious cases). There is a growing body of evidence that fully vaccinated people with no COVID symptoms pose little risk of transmitting the virus to others $(7,8)$. Given this evidence, governments will be hard-pressed to maintain that continued universal lockdowns are the least-restrictive way-or even a rational one - of fighting the pandemic.

Introducing a vaccine passport regime would be justified on civil liberty principles alone, at least until societies reach herd immunity (at which point unvaccinated people would be less of a threat to others, and discriminating by vaccination status would become harder to justify). But, as public-health experts and others have argued (9), vaccine passports would have the positive side effect of promoting vaccination, protecting many more from the virus. Throughout the world, vaccine hesitancy (10) is a barrier to achieving herd immunity. Up to $30 \%$ of Americans (11) say they are unlikely to get vaccinated. By offering an additional "carrot" of expanded freedom, vaccine passports would nudge at least some to overcome their hesitancy.

Sadly, many countries in the Global South currently have little vaccine access. The inequitable global distribution of vaccine access is deeply troubling, but not introducing vaccine passports on fairness grounds would do nothing to promote global access - if anything, it would do the opposite by deepening the adverse economic impact of the pandemic. Another difficult issue is the case of people 
who cannot be vaccinated for health reasons. The European Union is planning to provide the passports not only to the vaccinated, but also to those who exhibit antibodies from a previous infection or who have a recent negative test (12). Options such as these would further blunt the argument that vaccine passports unfairly discriminate by providing benefits to only part of the population.

Constitutional choices sometimes involve trading liberty for safety. This is not one of those times. Vaccine passports bridging the period to herd immunity would increase both liberty and safety, while responsibly catalyzing a return to (near) normalcy.

\section{ACKNOWLEDGMENTS}

We thank Eugen Volokh, Seana Shiffrin, Richard Schragger, Richard R.W. Brooks, and Mila Versteeg for comments to earlier drafts of this article. We are grateful to Hannah Burkard, Ozan Yildirim, and Patrick Krebs for excellent research assistance.

\section{REFERENCES}

1. Shah Z. Vaccination passports may infringe on fundamental freedoms and create a class of immunoprivileged, group says. National Post website. https://nationalpost. $\mathrm{com} /$ news/canada/vaccination-passports-may-infringe-on-fundamental-freedomsand-create-a-class-of-immunoprivileged-group-says. Published March 16, 2021. Accessed April 13, 2021.

2. Mariner WK, Annas GJ, Glantz LH. Jacobson v Massachusetts: it's not your great-great-grandfather's public health law. Am J Public Health. 2005;95:581-590.

3. Hunter ND. Living with Lawrence. Georgetown Law website. https://scholarship. law.georgetown.edu/facpub/116/. Published 2004. Accessed April 13, 2021.
4. Jacobson v. Massachusetts, 197 U.S. 11 (1905). JUSTIA, U.S. Supreme Court website. https://supreme.justia.com/cases/federal/us/197/11/. Accessed April 13, 2021.

5. Esbeck CH. The free exercise clause, its original public meaning, and the reconsideration of Employment Division of Oregon v. Smith. SSRN website. https://papers. ssrn.com/sol3/papers.cfm?abstract_id=3657246. Posted July 21, 2020. Accessed April 13, 2021.

6. No. 20-2175. ILLINOIS REPUBLICAN PARTY, et al., Plaintiffs-Appellants, v. J. B. PRITZKER, Governor of Illinois, Defendant-Appellee. uscourts.gov website. http://media.ca7.uscourts.gov/cgi-bin/rssExec.pl?Submit=Display\&Path=Y2020/ D09-03/C:20-2175:J:Wood:aut:T:fnOp:N:2574463:S:0. Accessed April 13, 2021.

7. Morris DZ, Mukherjee S. It's official: vaccinated people don't transmit COVID-19. Fortune website. https://fortune.com/2021/04/01/its-official-vaccinated-peopledont-transmit-covid-19/. Published April 1, 2021. Accessed April 13, 2021.

8. Dagan N, Barda N, Kepten E, et al. BNT162b2 mRNA Covid-19 vaccine in a nationwide mass vaccination setting. $N$ Engl J Med. February 24, 2021 [Epub ahead of print]. https://www.nejm.org/doi/full/10.1056/NEJMoa2101765.

9. Barak Corren N, Enoch D, Heyd D, Malcai O, Shur-Ofry M. Personal decisions, public consequences: on distinguishing between the vaccinated and the non-vaccinated in coronavirus management. SSRN website. https://papers.ssrn.com/sol3/papers.cfm?abstract_id=3793188. Written February 25, 2021. Revised March 2, 2021. Accessed April 21, 2021.

10. Krans B. How vaccine hesitancy could prolong the pandemic. Healthline website. https://www.healthline.com/health-news/how-vaccine-hesitancy-could-prolong-thepandemic. Written April 6, 2021. Accessed April 13, 2021.

11. Funk C, Tyson A. Growing share of Americans say they plan to get a COVID-19 vaccine - or already have. Pew Research Center website. https://www.pewresearch. org/science/2021/03/05/growing-share-of-americans-say-they-plan-to-get-a-covid-19vaccine-or-already-have/. Written March 5, 2021. Accessed April 13, 2021.

12. Kay N. Vaccine passports may save Europe's summer, but only for the lucky ones. CNN website. https://www.cnn.com/travel/article/eu-vaccination-passports-summer/ index.html. Published March 21, 2021. Accessed April 13, 2021. 